\title{
PENGARUH KOMBINASI PUPUK ORGANONITROFOS DAN PUPUK ANORGANIK TERHADAP NITROGEN TOTAL SELAMA PERTUMBUHAN JAGUNG MANIS (Zea Mays saccharata) DI TANAH ULTISOL
}

\author{
Gaby Chintya ${ }^{1}$, Dermiyati ${ }^{2}$, Sarno $^{2} \&$ Jamalam Lumbanraja $^{2}$ \\ ${ }^{1}$ Mahasiswa Jurusan Agroteknologi Fakultas Pertanian Universitas Lampung \\ ${ }^{2}$ Dosen Jurusan Agroteknologi Fakultas Pertanian Universitas Lampung \\ J1. Prof. Dr. Soemantri Brodjonegoro No. 1 Bandar Lampung 35145 \\ Emai: Chintya.gaby.gc@gmail.com
}

\begin{abstract}
ABSTRAK
Ketersediaan nitrogen di dalam tanah cukup rendah, karenanya dalam budidaya jagung manis perlu dilakukan kombinasi pemupukan yaitu dengan pupuk oganik dan pupuk anorganik. Tujuan dari penelitian ini yaitu untuk mengetahui pengaruh kombinasi pupuk Organonitrofos dan pupuk anorganik terhadap nitrogen total tanah selama pertumbuhan jagung manis (Zea Mays saccharata) di tanah Ultisol Taman Bogo, Lampung Timur. Penelitian ini dilakukan dari bulan April 2016 sampai dengan Maret 2017 bertempat di kebun percobaan Taman Bogo, Lampung Timur yang terdiri dari 11 perlakuan dengan 3 ulangan yang diacak dengan Rancangan Acak Kelompok. Perlakuan terdiri dari P0 (0\% Organonitrofos $+0 \%$ NPK), P1 (0\% Organonitrofos $+100 \%$ NPK), P2 (100\%Organonitrofos + 0\% NPK), P3 (100\% Organonitrofos $+25 \%$ NPK), P4 (100\% Organonitrofos + $50 \%$ NPK), P5 (100\% Organonitrofos + 75\% NPK), P6 (100\% Organonitrofos +100\% NPK), P7 (25\% Organonitrofos $+75 \%$ NPK), P8 (50\% Organonitrofos $+75 \%$ NPK), P9 (75\% Organonitrofos $+75 \%$ NPK), P10 (50\% Organonitrofos $+50 \%$ NPK). Analisis data diuji dengan ANOVA dan selanjutnya diuji dengan BNT pada taraf 5\%. Hasil penelitian menunjukkan bahwa kombinasi $100 \%$ Organonitrofos dan 50\% NPK dapat memberikan pengaruh terbaik terhadap nitrogen total tanah pada 78 HST (panen) dan tidak berbeda nyata dengan kombinasi 100\% Organonitrofos dan 0\% NPK. Selanjutnya, terdapat korelasi yang nyata antara Corganik terhadap N-total tanah 78 HST.
\end{abstract}

Kata Kunci : Kombinasi pupuk, nitrogen total tanah, pupuk Organonitrofos.

\section{PENDAHULUAN}

Tanaman jagung manis (Zea Mays saccharata) atau biasa dikenal dengan nama sweet corn mulai dikembangkan di Indonesia pada awal tahun 1980 dan merupakan komoditas palawija pangan di Indonesia yang layak dijadikan komoditas unggulan agrobisnis. Permintaan konsumen terhadap jagung manis terus meningkat hal ini dibuktikan dengan peningkatan produksi jagung manis pada tahun 2015 sampai 2017 dari 1.502.000 ton menjadi 1.720 .000 ton dengan penigkatan luas lahan dari 293.521 ha menjadi 464.712 ha (Kementerian Pertanian, 2014). Jagung manis dapat tumbuh di daerah beriklim sedang 
sampai tropis. Lahan kering di daerah tropis seperti Indonesia umumnya memiliki kesuburan tanah atau kandungan unsur hara yang rendah, dan pada umumnya tanaman jagung manis di tanam di tanah Ultisol (Mayadewi, 2007).

Tanah Ultisol dapat dicirkan oleh adanya akumulasi liat pada horizon bawah permukaan, memiliki kejenuhan basa berkisar $<35 \%$, $\mathrm{pH}$ tanah agak masam hingga sangat masam ( $\mathrm{pH} 3,10$ - 5) dan kapasitas tukar kation yang rendah. Salah satu upaya untuk mengatasi permasalahan rendahnya kesuburan tanah ditanah utisol maka dilakukan pemupukan yang merupakan faktor penentu keberhasilan budidaya jagung manis pada lahan kering (Prasetyo dan Suriadikata, 2006). Pemberian pupuk anorganik dengan dosis yang meningkat secara terus menerus tanpa dikombinasikan dengan pupuk organik dapat mengganggu keseimbangan sifat tanah sehingga menurunkan produktivitas lahan dan mempengaruhi produksi tanaman.

Jagung manis memerlukan unsur hara nitrogen, fosfor dan kalium yang cukup tinggi dan diantara ketiga unsur hara tersebut nitrogen yang paling banyak dibutuhkan. Nitrogen merupakan salah satu unsur hara makro bagi pertumbuhan tanaman yang pada umumnya sangat diperlukan pada pertumbuhan vegetatif tanaman seperti akar, batang dan daun (Sutejo, 1992). Pada penelitian ini digunakan kombinasi pupuk organik yaitu pupuk Organonitrofos dan pupuk anorganik yaitu NPK. Diharapkan dengan adanya pemberian pupuk organik dan kombinasinya dengan pupuk anorganik dapat meningkatkan $\mathrm{N}$-total tanah.
Penelitian ini bertujuan untuk mengetahui pengaruh kombinasi pupuk Organonitrofos dan pupuk anorganik terhadap $\mathrm{N}$-total tanah selama pertumbuhan jagung manis (Zea Mays saccharata) di tanah Ultisol, Taman Bogo, Lampung Timur.

\section{METODE PENELITIAN}

Penelitian ini dilaksanakan di kebun percobaan Taman Bogo, Lampung Timur pada April 2016 sampai Maret 2017. Sedangkan untuk analisis tanah dilakukan di Laboratorium Ilmu Tanah Universitas Lampung. Alat-alat yang digunakan dalam pengambilan sampel tanah di lapang yaitu bor tanah, kantung plastik, meteran dan spidol, untuk alat-alat yang digunakan di laboratorium yaitu gelas ukur, tabung reaksi, timbangan tanah, labu kjeldhal, alat titrasi, alat destilasi dan alat desktrusi. Sedangkan bahan-bahan yang digunakan pada penelitian ini yaitu sekam bakar(biochar), pupuk organonitrofos, benih jagung varietas Bonanza F1, pupuk anorganik (Urea, TSP, KCl), furadan, herbisida, insektisida, sampel tanah 15 HST, 45 HST, dan panen, selen, larutan $\mathrm{H}_{2} \mathrm{SO}_{4}, \mathrm{NaOH}$, asam borat, dan aquades.

Penelitian ini terdiri dari 11 perlakuan dengan 3 kali ulangan yang disusun dengan menggunakan RAK (Rancangan Acak Kelompok). Perlakuan 100\% Organonitrofos yaitu $1000 \mathrm{~kg} \mathrm{ha}^{-1}$, sedangkan perlakuan $100 \%$ NPK yaitu $600 \mathrm{~kg}$ urea, $300 \mathrm{~kg}$ SP$36,150 \mathrm{~kg} \mathrm{KCl}$. Masing-masing perlakuan yaitu P0 $(0 \%$ Organonitrofos $+0 \%$ NPK $)$, P1 $(0 \%$ Organonitrofos $+100 \%$ NPK), P2 (100\%Organonitrofos $+0 \%$ NPK), P3 (100\% Organonitrofos $+25 \%$ NPK), P4 (100\% 
Organonitrofos + 50\% NPK), P5 (100\%

Organonitrofos $+75 \%$ NPK), P6 (100\%

Organonitrofos $+100 \%$ NPK), P7 (25\%

Organonitrofos $+75 \%$ NPK), P8 (50\%

Organonitrofos $+75 \%$ NPK), P9 (75\%

Organonitrofos $+75 \%$ NPK $),$ P10 $(50 \%$

Organonitrofos $+50 \%$ NPK). Setiap perlakuan

diberikan dolomit dan biochar dengan tujuan sebagai

bahan pembenah tanah dan juga agar kemasaman tanah

Ultisol tidak menjadi faktor pembatas dalam pertumbuhan tanaman jagung manis. Homogenitas ragam diuji dengan menggunakan uji Barlett, sedangkan aditivitas data diuji dengan uji Tukey. Jika asumsi terpenuhi data dianalisis dengan sidik ragam. Perbedaan nilai tengah diuji dengan BNT (Beda Nilai Terkecil) pada taraf $5 \%$. Untuk mengetahui hubungan antara $\mathrm{N}$ total tanah dengan kadar air tanah, $\mathrm{pH}$ tanah, C-organik, serapan $\mathrm{N}$, berangkasan kering tanaman, bobot tongkol dengan kelobot dilakukan dengan uji korelasi.

Variabel utama pada penelitian ini yaitu N-total tanah yang dianalisis dengan metode kjeldhal, sedangkan untuk variabel pendukung pada penlitian ini yatu pH tanah, kadar air, C-organik tanah, serapan N, bobot tongkol dengan kelobot dan berangkasan kering tanaman.

\section{HASIL DAN PEMBAHASAN}

\section{Pengaruh Kombinasi Pupuk Organonitrofos dan}

\section{Pupuk Anorganik terhadap N-total Tanah}

Dari hasil analisis ragam menunjukkan bahwa kombinasi pupuk organonitrofos dan pupuk anorganik tidak berpengaruh nyata terhadap $\mathrm{N}$-total tanah pada 15 HST dan 45 HST, tetapi berpengaruh nyata terhadap N-total tanah pada 78 HST (panen).

Berdasarkan hasil uji BNT 5\% kombinasi pupuk Organonitrofos dan pupuk anorganik terbaik pada 78 HST (panen) terhadap N-total tanah yaitu pada P4 (100\% Organonitrofos + 50\% NPK) dan tidak berbeda nyata pada P2 (100\% Organonitrofos + 0\% NPK), P5 (100\% Organonitrofos + 75\% NPK) dan P9 (75\% Organonitrofs + 75\% NPK). Namun, bila memperhitungkan kebutuhan jumlah pupuk yang digunakan, maka P2 sudah dapat memberikan pengaruh nyata terhadap $\mathrm{N}$-total tanah pada saat panen.

Kombinasi pupuk Organonitrofos dan pupuk anorganik pada 78 HST dapat berpengaruh nyata dikarenakan pada 78 HST (panen) tanaman jagung manis sudah pada fase generatif akhir yaitu dengan ditandai berhentinya masa pertumbuhann jagung manis, sehingga tanaman jagung manis sudah tidak banyak

Tabel 1. Rangkuman hasil analisis ragam kombinasi pupuk Organonitrofos dan pupuk Anorganik terhadap N-total tanah pada 15,45 dan 78 HST

\begin{tabular}{ll}
\hline & Analisis ragam N-total \\
\hline N-total 15 HST & tn \\
N-total 45 HST & tn \\
N-total 78 HST & $*$ \\
\hline
\end{tabular}

Keterangan: $*$ = berbeda nyata pada taraf $5 \%, \mathrm{tn}=$ tidak berbeda nyata pada taraf $5 \%$. 
memerlukan unsur hara $\mathrm{N}$ dalam jumlah yang banyak.

Selain itu, pada saat setelah panen $\mathrm{N}$ didalam tanah telah temineralisasi secara sempurna. Proses mineralisasi melibatkan dua reaksi yaitu rekasi aminisasi dan amonifikasi yang terjadi melalui aktivitas mikroorganisme heterotrofik (Halvin dkk., 1999). Nitrogen yang tersisa didalam tanah adalah $\mathrm{N}$-total dari keseluruhan setelah terpakai oleh tanaman selama masa pertumbuhan dan produksi.
Dinamika N-total tanah akibat pemberian pupuk Organonitrofos dan kombinasinya dengan pupuk anorganik pada tanaman jagung manis (Zea mays saccharata) mengalami penurunan dari $15 \mathrm{HST}$, 45 HST sampai dengan 78 HST (panen). Hal ini disebabkan karena selama masa pertumbuhan dan produksi jagung manis memerlukan unsur hara $\mathrm{N}$ yang cukup tinggi dibandingkan dengan unsur hara lainnya, selain itu dekomposisi dan mineralisasi $\mathrm{N}$ di dalam tanah

Tabel 2. Uji BNT 5\% pengaruh kombinasi pupuk Organonitrofos dan pupuk anorganik terhadap N-total tanah 78 HST

\begin{tabular}{|c|c|c|}
\hline No & Perlakuan Kombinasi Pupuk & $\mathrm{N}$-total $(\%)$ \\
\hline 1 & P0 (0\%Organonitrofos + 0\%NPK) & $0,09 \mathrm{c}$ \\
\hline 2 & P1 (0\% Organonitrofos $+100 \%$ NPK) & $0,11 b$ \\
\hline 3 & P2 (100\% Organonitrofos + 0\% NPK) & $0,12 \mathrm{ab}$ \\
\hline 4 & P3(100\% Organonitrofos + 25\% NPK) & $0,11 \mathrm{~b}$ \\
\hline 5 & P4 (100\% Organonitrofos $+50 \%$ NPK $)$ & 0,13 a \\
\hline 6 & P5 (100\% Organonitrofos $+75 \%$ NPK) & $0,12 \mathrm{ab}$ \\
\hline 7 & P6 (100\% Organonitrofos $+100 \%$ NPK) & $0,11 \mathrm{~b}$ \\
\hline 8 & P7 (25\% Organonitrofos + 75\% NPK) & $0,11 \mathrm{~b}$ \\
\hline 9 & P8 (50\% Organonitrofos $+75 \%$ NPK) & $0,11 \mathrm{~b}$ \\
\hline 10 & P9 (75\% Organonitrofos $+75 \%$ NPK) & $0,12 \mathrm{ab}$ \\
\hline \multirow[t]{2}{*}{11} & P10 (50 Organonitrofos $+50 \%$ NPK) & $0,11 \mathrm{~b}$ \\
\hline & BNT 5\% & 0,01 \\
\hline
\end{tabular}

Keterangan: Kolom yang diikuti huruf yang sama tidak berbeda nyata dengan uji BNT taraf 5\%.

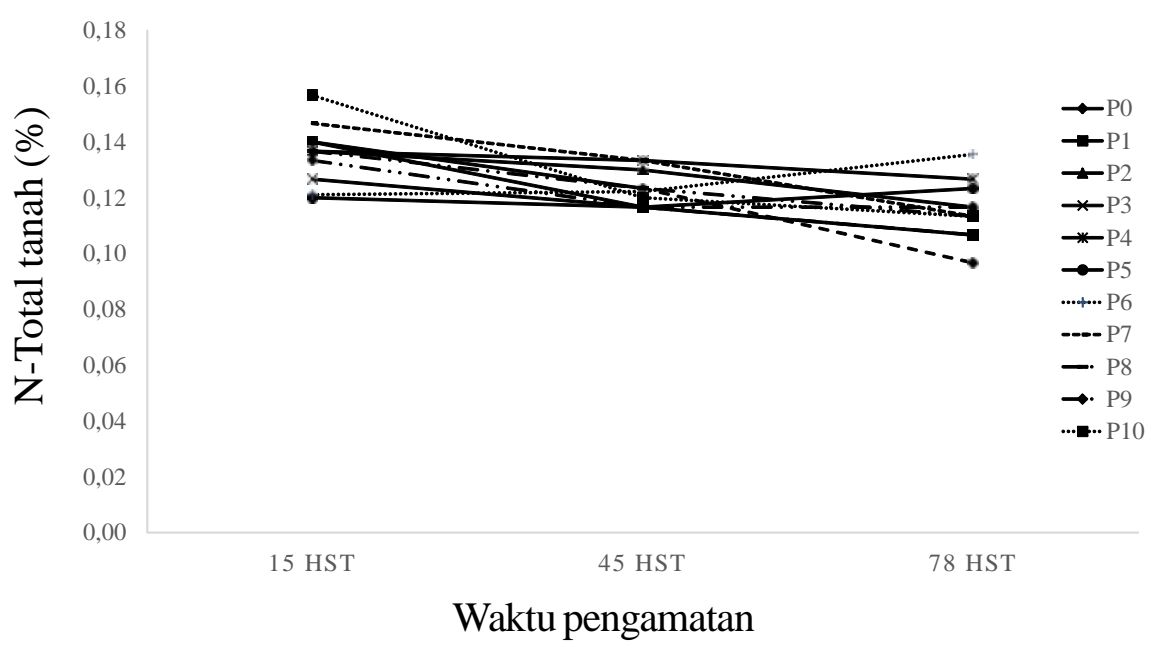

Gambar 1. Dinamika kandungan N-total tanah yang dikombinasikan dengan pupuk Organonitrofos dan pupuk anorganik selama pertumbuhan jagung manis (Zea mays saccharta) pada 15, 45 dan 78 HST. 
Tabel 3. Hasil Analisis sifat kimia tanah awal Taman Bogo dan Kandungan yang terdapat didalam Pupuk Organonitrofos

\begin{tabular}{lc}
\hline \multicolumn{1}{c}{ Jenis Analisis } & Nilai \\
\hline $\mathrm{pH}$ & 4,61 \\
N-total (\%) & 0,08 \\
P-tersedia (ppm) & 3,25 \\
K-dd (ppm) & 0,16 \\
C-organik (\%) & 0,95 \\
pH pupuk Organonitrofos & 5,59 \\
C-organik (\%) pupuk Organonitrofos & 9,52 \\
N-total (\%) pupuk Organonitrofos & 1,13 \\
P-total (\%) pupuk Organonitrofos & 5,58 \\
K-total (\%) pupuk Organonitrofos & 0,68 \\
\hline
\end{tabular}

memerlukan waktu yang cukup lama untuk dapat berpengaruh di dalam tanah. Hal ini selaras dengan penelitian Nugraha (2010) yang menyatakan bahwa kadar nitrogen total dalam tanah akan terus mengalami penurunan selaras dengan bertambahnya umur tanaman.

\section{Hasil Analisis Kimia Tanah pada Awal dan Setelah Panen}

Berdasarkan hasil analisis tanah ultisol awal (Tabel 3) tanah yang digunakan dalam penelitian ini memiliki pH dengan kriteria masam, N-total dan Kdd dengan kriteria rendah, serta P-tersedia dan Corganik dengan kriteria sangat rendah. Hal ini sejalan dengan kriteria tanah ultisol pada umumnya yaitu memiliki pH masam dan kandungan unsur hara serta C-organik yang rendah. Sedangkan Pupuk Organontirofos yang digunakan pada penelitian ini memiliki kandungan $\mathrm{pH}$ yang tergolong agak masam, P-total sedang, N-total dan K-total tinggi, serta Corganik yang sangat tinggi. Selain itu, Pupuk Organonitrofos juga mengandung mikroba pelarut $\mathrm{P}$ dan bakteri penambat N, dengan demikian Kombinasi
Pupuk Organonitrofos dan pupuk anorganik diberikan untuk meningkatkan kandungan unsur hara selama budidaya tanaman jagung manis.

Dari hasil analisis sifat kimia tanah Taman Bogo, pH tanah awal bersifat masam 4,61 (Tabel 3). Namun, setelah diberi perlakuan, $\mathrm{pH}$ meningkat (Tabel 4) dengan perubahan kriteria menjadi agak masam. Selain itu, pada perlakuan P0 yaitu tanpa perlakuan pupuk terjadi peningkatan $\mathrm{pH}$ dari 4,61 menjadi 5,24. Hal ini disebabkan karena pada semua perlakuan diberikan dolomit dan biochar sebagai bahan pembenah tanah. Pemberian dolomit pada tanah masam bertujuan untuk menigkatkan $\mathrm{pH}$, meniadakan racun dari Alumunium (Al), menyediakan unsur Ca bagi tanaman dan meningkatkan ketersediaan beberapa unsur hara seperti P, Mo dan N (Dariah dkk., 2015).

P-tersedia tanah juga mengalami perubahan yang sangat signifikan. P-tersedia tanah sebelum diaplikasikan pupuk sebesar 3,43 ppm. Sedangkan Ptersedia tanah sesudah diaplikasikan perlakuan pupuk Organonitrofos dan kombinasinya berkisar dari 11,01 ppm sampai 28,94 ppm. Peningkatan P-tersedia 
tertinggi yaitu pada perlakuan P3 (100\% Organonitrofos $+25 \%$ NPK). Hal ini dapat terjadi karena pupuk Organonitrofos mengandung unsur hara $\mathrm{P}$ sebesar $5,58 \%$. Selain itu didalam pupuk Organonitrofos terdapat bakteri pelarut $\mathrm{P}$ dan kandungan pupuk anorganik yang menyumbang unsur hara P. aktivitas mikroba pelarut $\mathrm{P}$ akan menghasilkan asam-asam organik yang dengan meningkatnya asamasam organik tersebut biasanya diikuti dengan penurunan $\mathrm{pH}$. Sehingga mengakibatkan terjadinya pelarutan P yang terikat oleh Ca (Elfiati, 2005).

Kandungan C-organik pada beberapa perlakuan mengalami peningkatan kecuali pada perlakuan P1 (0\% Organonitrofos + 100\% NPK) yang memiliki kandungan C-organik terendah sebesar 0,76\% dibandingkan dengan perlakuan lainnya. Sedangkan Corganik tertinggi yaitu terdapat pada perlakuan P6 $(100 \%$ Organonitrofos $+100 \%$ NPK) sebesar $1,77 \%$. Hal ini menunjukkan kandungan C-organik dipengaruhi oleh penggunaan pupuk Organonitrofos. Menurut Afandi dkk (2015), pemberian bahan organik meningkatkan kandungan C-organik dan peningkatan C-organik dapat mempengaruhi sifat tanah menjadi lebih baik secara fisik, kimia dan biologi.

Pada K-dd terjadi Penurunan pada perlakuan P0, P1 dan P7 yang memiliki kandungan pupuk Organonitrofos 0-25\% dari 0,16 ppm menjadi 0,13 ppm, sedangkan kandungan K-dd tertinggi yaitu pada perlakuan P5 (100\% Organonitrofos $+75 \%$ NPK) sebesar 0,34 ppm dan tergolong rendah. Hal ini dapat terjadi karena pemberian bahan organik ke dalam tanah dapat berpengaruh terhadap K-dd tanah. Menurut Sari (2015), pemberian pupuk Organonitrofos dan pupuk kimia dengan berbagai kombinasinya dapat meningkatkan K-dd tanah pada tanaman jagung awal musim tanam pertama dan akhir musim tanam sebesar $0,29 \mathrm{ppm}$ dengan pemberian $150 \mathrm{~kg}$ urea ha ${ }^{-1}, 100$ $\mathrm{kg}$ SP-36, $50 \mathrm{~kg} \mathrm{KCl}, 1.500 \mathrm{~kg}$ Organonotrofos.

Tabel 4. Hasil analisis kimia tanah setelah panen yang sudah di kombinasikan pupuk organonitrofos dan pupuk anorganik

\begin{tabular}{lccccccccccc}
\hline \multirow{2}{*}{ Analisis } & \multicolumn{10}{c}{ Perlakuan } \\
\cline { 2 - 11 } & P0 & P1 & P2 & P3 & P4 & P5 & P6 & P7 & P8 & P9 & P10 \\
\hline pH & 5,24 & 5,53 & 5,34 & 5,32 & 5,11 & 5,53 & 5,63 & 5,25 & 5,38 & 5,48 & 5,34 \\
P-tersedia & 11,13 & 11,01 & 19,93 & 28,94 & 25,32 & 21,44 & 21,31 & 15,01 & 16,18 & 23,16 & 15,32 \\
K-dd & 0,13 & 0,13 & 0,25 & 0,28 & 0,24 & 0,34 & 0,26 & 0,13 & 0,18 & 0,21 & 0,19 \\
C-organik & 0,84 & 0,76 & 1,34 & 1,46 & 1,42 & 1,11 & 1,77 & 1,56 & 1,26 & 1,29 & 1,11 \\
\hline
\end{tabular}

Keterangan: P0 (0\% Organonitrofos + 0\% NPK), P1 (0\% Organonitrofos + 100\% NPK), P2 (100\% Organonitrofos $+0 \%$ NPK), P3 (100\% Organonitrofos $+25 \%$ NPK), P4 $(100 \%$ Organonitrofos $+50 \%$ NPK), P5 (100\% Organonitrofos $+75 \%$ NPK), P6 (100\% Organonitrofos $+100 \%$ NPK), P7 (25\% Organonitrofos $+75 \%$ NPK), P8 (50\% Organonitrofos $+75 \%$ NPK), P9 (75\% Organonitrofos $+75 \%$ NPK) dan P10 (50\% Organonitrofos $+50 \%$ NPK). 
Uji Korelasi antara Beberapa Sifat Tanah, Serapan N, dan Produksi Tanaman dengan N-total Tanah

Berdasarkan hasil uji korelasi tidak terdapat korelasi antara $\mathrm{pH}$ tanah maupun kadar air terhadap N-total tanah pada $15,45,78$ HST, dan pada 78 HST (panen). Demikian pula tidak terdapat korelasi antara $\mathrm{N}$-total tanah terhadap bobot berangkasan kering tanaman, bobot tongkol dengan kelobot dan serapan $\mathrm{N}$ tanaman. Namun terdapat korelasi yang nyata antara C-organik tanah dengan Nitrogen total tanah pada 45 HST. Hal ini diduga karena beberapa sifat kimia tanah seperti pH dan kadar air tidak dapat mempengaruhi nilai $\mathrm{N}$-total tanah. Hal ini dapat saja terjadi karena waktu penelitian yang hanya sampai musim tanam jagung pertama, sehingga masih belum terlihat korelasi antara $\mathrm{pH}$ dan kadar air yang dapat mempengaruhi nilai $\mathrm{N}$-total tanah, karena perlu waktu yang cukup lama untuk pupuk organik terdekomposisi secara menyeluruh.

\section{KESIMPULAN}

Kesimpulan dari penelitian ini yaitu: (1) N-total tanah tertinggi terdapat pada saat panen tanaman jagung manis dengan kombinasi pupuk 100\% pupuk Organonitrofos dan 50\% pupuk anorganik (P4) dan tidak berbeda nyata pada P2, P5 dan P9. (2) Kombinasi $100 \%$ pupuk Organonitrofos dan 0\% NPK (P2) dapat meningkatkan N-total tanah pada 78 HST, dan dapat mengurangi penggunaan pupuk anorganik.

\section{DAFTAR PUSTAKA}

Afandi, F. N., B. Siswanto. dan Y. Nuraini. 2015. Pengaruh Pemberian Berbagai Jenis Bahan Organik terhadap Sifat Kimia Tanah pada Pertumbuhan dan Produksi Tanaman Ubi Jalar di Entisol Ngrangkah Pawon, Kediri. J. Tanah dan Sumberdaya Lahan. 2 (2): 237 - 244.

Dariah A., S. Susono., Neneng L., Nurida, Wiwik H, dan Etty P. 2015. Pembenah Tanah untuk Meningkatkan Produktivitas Lahan Pertanian. Bogor. J. Sumberdaya Lahan. 9 (2) : 67-84.

Dermiyati. 2015. Sistem Petanian Organik Berkelanjutan. Plantaxia. Yogyakarta. 121 hlm.

Elfianti, D. 2005. Peranan Mikroba Pelarut Fosfat terhadap Tanaman. Fakultas Peternakan Universitas Sumatra Utara. Hal. 4-5.

Halvin, J. L., J. D. Beaton, S. L. Tisdale, and W. L. Nelson. 1999. Soil Fertility and Fertilizers, $6^{\text {th }}$ Edition. Prentice Hall. New Jersey. $515 \mathrm{hlm}$.

Kementerian Pertanian RI. 2014. Produksi Jagung Manis Menurut Provinsi. (http:// www. pertanian.go.id/ap_pages/mod/data) diakses pada 15 Desember 2017.

Mayadewi, N. N. A. 2007. Pengaruh Jenis Pupuk Kandang dam Jarak Tanam terhadap Pertumbuhan Gulma dan Jagung Manis. $J$. Agritrop. 26 (4) : 154-159. 
Nugraha, N. M. 2010. Kajian Penggunaan Pupuk Organik dan Jenis Pupuk N terhadap Kadar $\mathrm{N}$ tanah, Serapan N dan Hasil Tanaman Sawi

(Brassica juncea L.) pada Tanah Litosol Gemolong. Skripsi. Universitas Sebelas Maret. Surakarta.

Prasetyo, B. H., D. A Suriadikarta. 2006. Karakteristik, Potensi, dan Teknologi Pengelolaan Tanah Ultisol untuk Pengembangan Pertanian Lahan Kering di Indonesia. Balai Penelitian dan Pengembangan Sumberdaya Lahan Pertanian. Bogor. Jurnal Litbang Pertanian. 25(2) : 6-8.

Rosmarkam, A. dan N. W. Yuwono. 2002. Ilmu Kesuburan Tanah. Penerbit Kanisius. Yogyakarta . $224 \mathrm{hlm}$.
Sari E. P, J. Lumbanraja, H. Buchari, dan A. Niswati. 2013. Uji Efektivitas Pupuk Organonitrofos dan Kombinasinya dengan Pupuk Kimia terhadap Pertumbuhan, Serapan Hara dan Produksi Tanaman Jagung Manis (Zea mays saccharata) di Musim Tanam Ketiga pada Tanah Gedung Meneng. Jurnal Penelitian Pertanian Terapan. 15(3): 174:182.

Sutejo, M. M. 1992. Tanaman Jagung. Penebar Swadaya. Jakarta. $59 \mathrm{hlm}$. 